Edith Cowan University

Research Online

ECU Publications Post 2013

$1-1-2014$

\title{
A new troglobitic ideoroncid pseudoscorpion (Pseudoscorpiones: Ideoroncidae) from southern Africa
}

Mark S. Harvey

Edith Cowan University

Gerhard Du Preez

Follow this and additional works at: https://ro.ecu.edu.au/ecuworkspost2013

Part of the Animal Sciences Commons

10.1636/K13-55.1

Harvey M.S., Du Preez G. (2014). A new troglobitic ideoroncid pseudoscorpion (Pseudoscorpiones: Ideoroncidae)

from southern Africa. Journal of Arachnology, 42(1), 105-110. Available here

This Journal Article is posted at Research Online.

https://ro.ecu.edu.au/ecuworkspost2013/546 


\title{
A new troglobitic ideoroncid pseudoscorpion (Pseudoscorpiones: Ideoroncidae) from southern Africa
}

Mark S. Harvey: Department of Terrestrial Zoology, Western Australian Museum, Locked Bag 49, Welshpool DC, Western Australia 6986, Australia; Research Associate: Division of Invertebrate Zoology, American Museum of Natural History, 79th Street at Central Park West, New York, New York 10024-5192, USA; Research Associate: Department of Entomology, California Academy of Sciences, Golden Gate Park, San Francisco, California 94103-3009 USA; Adjunct Professor: School of Animal Biology, University of Western Australia, Crawley, Western Australia 6009, Australia; Adjunct Professor: School of Natural Sciences, Edith Cowan University, Joondalup, Western Australia 6027, Australia. E-mail: mark.harvey@museum.wa.gov.au

Gerhard Du Preez: Unit for Environmental Sciences and Management, Potchefstroom Campus, North-West University, Private Bag X6001, Potchefstroom 2520, South Africa

\begin{abstract}
The first blind African species of Ideoroncidae is described from a cave in northwestern Botswana, Botswanoncus ellisi, representing a new genus and a new species. Apart from the complete lack of eyes, it is also unusual in having the lowest recorded number of trichobothria of any adult ideoroncid with 17 on the fixed finger and nine on the movable finger.
\end{abstract}

Keywords: Taxonomy, morphology, Botswana, new genus

The pseudoscorpion family Ideoroncidae comprises 13 genera and 70 species found in Africa, Asia and the Americas (Harvey 2013; Harvey \& Muchmore 2013). The majority occur in tropical ecosystems, but some occur in drier regions such as the southwestern USA and Mexico, Chile and Argentina, and the deserts of the Middle East. Ideoroncids have the combination of two unique morphological features, supernumerary trichobothria and the sub-basal position of the median maxillary lyrifissure (Harvey 1992; Harvey \& Muchmore 2013). Another unusual feature, the division of the median genital sac of the male genitalia into two distinct parts, is also found in some species currently attributed to the family Syarinidae (e.g., Vachon 1938, 1954, 1969; Chamberlin 1952; Mahnert 1980; Harvey 1992).

The African ideoroncid fauna (Fig. 3) consists of four genera, Afroroncus Mahnert 1981, Dhanus Chamberlin 1930, Nannoroncus Beier 1955 and Negroroncus Beier 1931 (Harvey 2013). The genera Nannoroncus and Afroroncus are restricted to forested habitats in Kenya (Mahnert 1981). Three species of the genus Dhanus are known from the island of Socotra located off the Somali coast (Mahnert 2007). This genus is otherwise known from the Middle East (Afghanistan and Iran), India and southeast Asia (Harvey 2013). Negroroncus is the most widespread African genus, being found throughout Kenya, eastern Democratic Republic of Congo and northern Tanzania, as well as individual outlying species from Zimbabwe and the Republic of Congo (Mahnert 1981; Harvey 2013).

Among a small collection of pseudoscorpions taken from a cave in the Gcwihaba region of northwestern Botswana, the junior author found a small ideoroncid that completely lacks eyes (Fig. 4). Eyeless ideoroncids are elsewhere only known from the New World: Albiorix anophthalmus Muchmore 1999 from a cave in Arizona, USA (Muchmore \& Pape 1999), Ideoroncus anophthalmus Mahnert 1984 and I. cavicola Mahnert 2001 from Brazil (Mahnert 1984, 2001) and five species of Typhloroncus 1979 from caves in Mexico and epigean ecotypes in the US Virgin Islands (Muchmore 1979,
1982, 1986; Harvey \& Muchmore 2013). The only cavedwelling ideoroncids from Africa are Negroroncus aelleni Vachon 1958 from the Republic of Congo and N. jeanneli Vachon 1958 from Tanzania (Vachon 1958), but neither species is completely eyeless, even though the eyes are small (Vachon 1958).

An initiative by the Botswana government to discover and explore unknown caves with the aim to promote caving in the tourism industry led to the discovery of several caves with no natural openings in the northwestern Gcwihaba region of Botswana. These caves were discovered through gravimetrical surveys of dolomitic outcrops. This technique identifies isolated subterranean cavities that are subsequently penetrated by means of drilling $700 \mathrm{~mm}$ vertical shafts. In 2010 efforts led to the discovery of a cave system named Diviners Cave. The drilled shaft, with a surface entrance altitude of $1056 \mathrm{~m}$ a.s.l., penetrates through 50 meters of rock into the cave. Exploration revealed an extensive cave system (Fig. 1) at several levels, with chambers of up to up 180 meters in diameter. Within the sealed cave we found areas where the roots of wild fig trees (Ficus cordata) penetrate the caves associated with sand and water drips. In these areas we found a diversity of invertebrates including diplurans, centipedes and termites. Although the cave does not reach the water table, the relative humidity exceeds $95 \%$ with a fairly constant temperature of $27^{\circ} \mathrm{C}\left( \pm 2^{\circ} \mathrm{C}\right)$. Prior to drilling to open the cave, the system was under a high $\mathrm{CO}_{2}$ pressurized atmosphere, making the circumstances in which the cavernicoles survived quite different from other natural caves in southern Africa.

Our study of the specimens revealed a number of unusual features, including the lowest number of trichobothria thus far recorded for an adult ideoroncid (Table 1), and a short arolium that lacks a ventral hook-shaped process. Apart from being a distinctive new species, we also suggest that it represents a previously undescribed genus. Therefore, we here provide a description and name the species to highlight its distinctive morphology and habitat. 

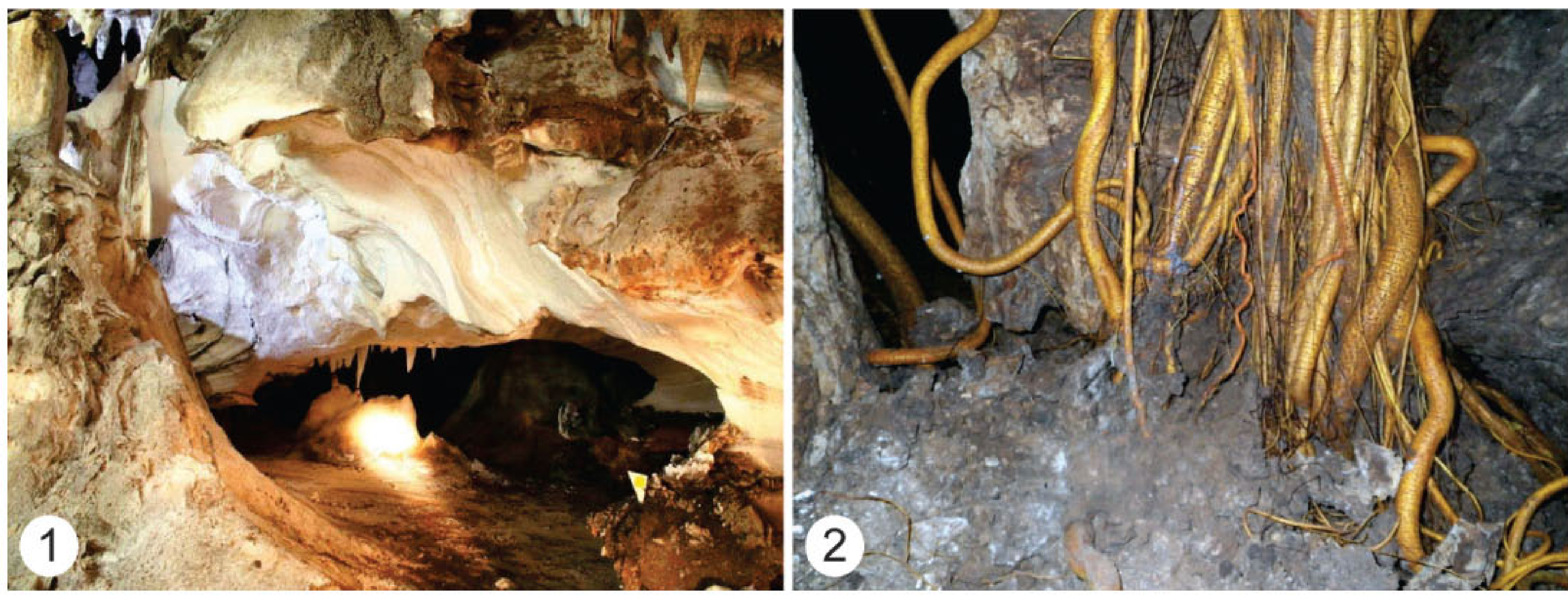

Figures 1, 2.-1. The type locality of Botswanoncus ellisi, Diviners Cave, Botswana (Photo: Gerhard Jacobs); 2. Roots of the fig tree (Ficus cordata): the specimens were collected from the soil below the roots.

\section{METHODS}

The specimens examined in this study were mainly sampled with pitfall traps. Each trap was neatly buried in the soft sand associated with wild fig tree roots (Fig. 2) and half-filled with $75 \%$ ethanol. Also, some specimens were caught by hand or extracted from soil samples using Berlese funnels. These specimens are lodged in the Western Australian Museum, Perth (WAM) and the KwaZulu-Natal Museum, Pietermaritzburg (NMSA), and were studied using temporary slide mounts prepared by immersion of the specimen in lactic acid at room temperature for several days. They were then mounted on microscope slides with a $10 \mathrm{~mm}$ coverslip supported by small sections of 0.25 or $0.35 \mathrm{~mm}$ diameter nylon fishing line. After study the specimens were returned to
$75 \%$ ethanol with the dissected portions placed in $12 \times 3 \mathrm{~mm}$ glass genitalia microvials (BioQuip Products, Inc.). Specimens were examined with a Leica MZ-16A dissecting microscope and a Leica DM2500 compound microscope, the latter fitted with interference contrast, and illustrated with the aid of a drawing tube attached to the compound microscope.

Measurements were taken at the highest possible magnification using an ocular graticule. Terminology and mensuration mostly follow Chamberlin (1931), with the exception of the nomenclature of the pedipalps and legs, and with some minor modifications to the terminology of the trichobothria (Harvey 1992), chelicera (Judson 2007) and faces of the appendages (Harvey et al. 2012).

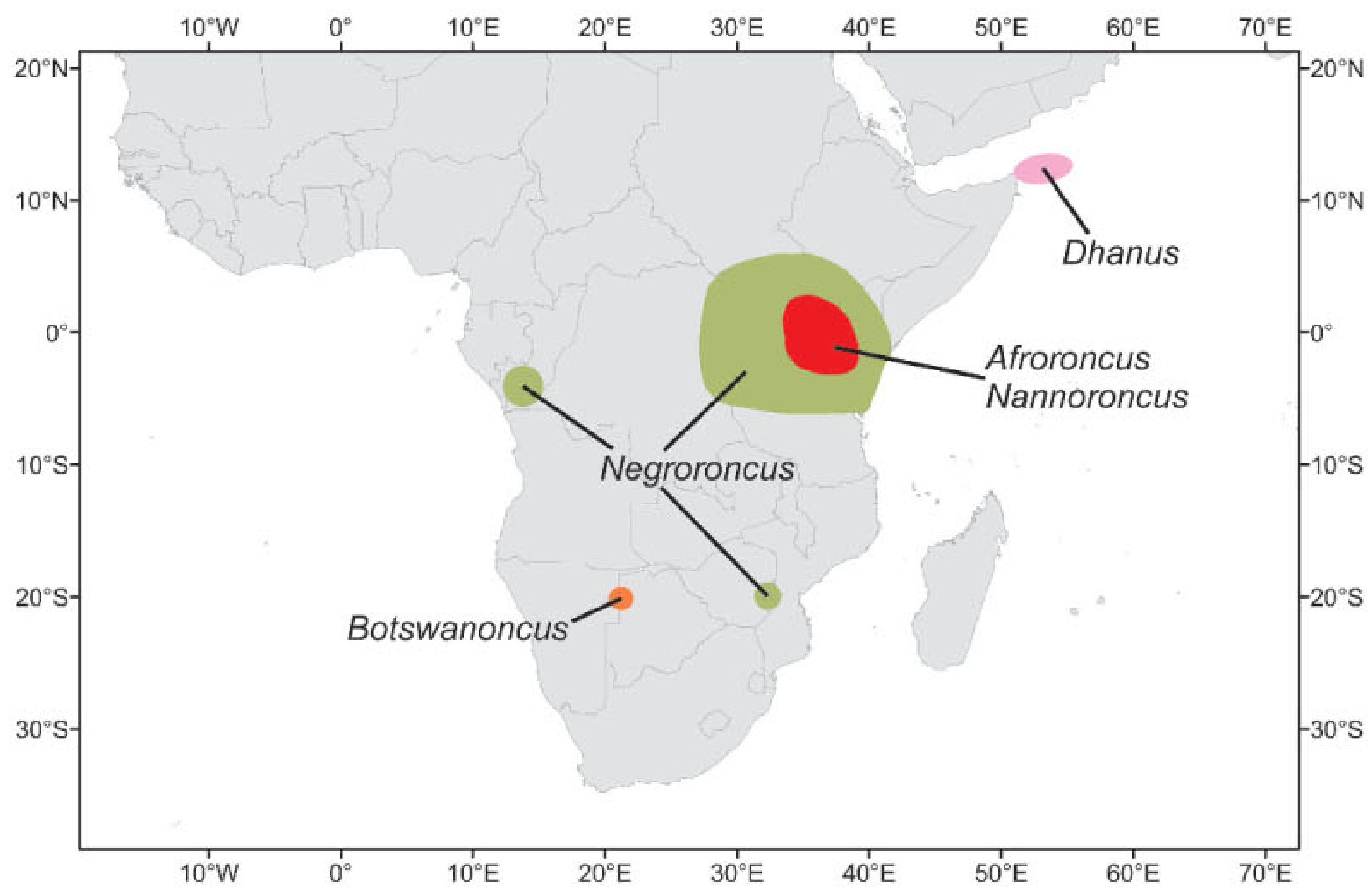

Figure 3.-Distribution of ideoroncid genera in Africa. 


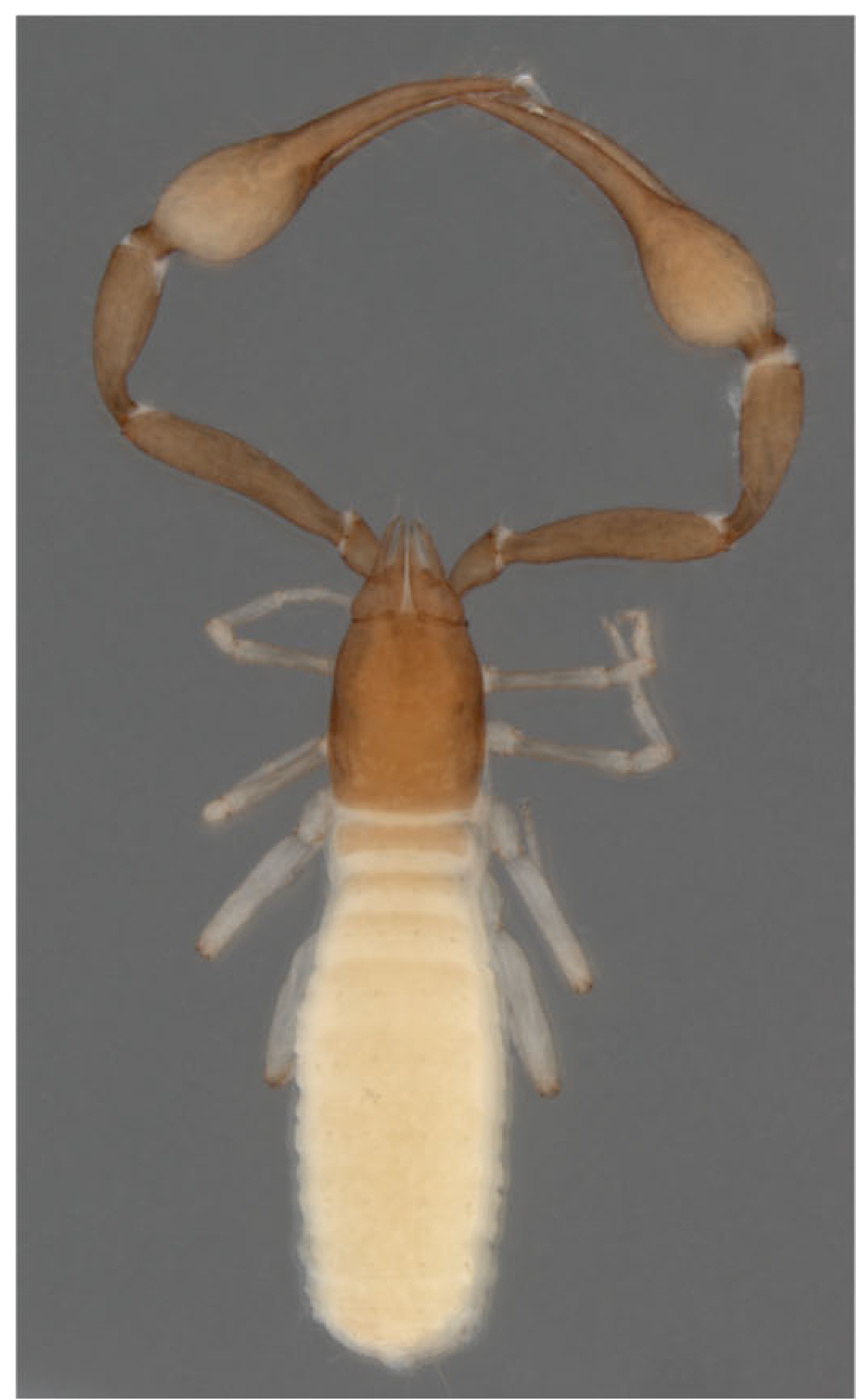

Figure 4.-Botswanoncus ellisi, new species, female holotype, prior to dissection, dorsal aspect.

The description was compiled using the DELTA (DEscription Language for Taxonomy) Editor computer program, version 1.0-Beta (available at http://code.google.com/p/open-delta/) (Dallwitz et al. 1999).

\section{SYSTEMATICS}

\section{Family Ideoroncidae Chamberlin 1930 \\ Genus Botswanoncus gen. nov.}

Type species. - Botswanoncus ellisi new species

Diagnosis.-Botswanoncus is the only ideoroncid genus with a short arolium that lacks a ventral hook on the arolium. It also differs from other ideoroncids by the presence of only 17 trichobothria on the fixed chelal finger and nine trichobothria on the movable chelal finger (Table 1) (Figs. 11, 12), and from all other African ideoroncids by the complete lack of eyes (Fig. 5).

Description.-Adult female (male unknown): Chelicera (Fig. 9): hand with 5 setae; movable finger with 1 sub-distal seta; all setae acuminate; galea present, simple, long and slender; lamina exterior absent; serrula exterior connected to chelicera finger for only part of length; not modified to form velum; rallum (Fig. 10) with 4 blades, all with anterior spinules, basal and sub-basal blades shorter than others.

Pedipalp (Fig. 8): long and slender. Fixed finger with 17 trichobothria (Figs 11, 12): $e b, e s b, e t$, isb and $i t$ regions each with 1 trichobothrium; est region with 6 trichobothria; $i b$ region with 3 trichobothria; ist region with 3 trichobothria; et slightly distal to it. Movable finger with 9 trichobothria (Figs. 11, 12): $b, s b$ and $s t$ regions each with 1 trichobothrium; $t$ region with 6 trichobothria. Chelal teeth (Fig. 11) juxtadentate, with fixed finger chelal teeth low and flattened, and movable finger chelal teeth low; venom apparatus present in both chelal fingers; venom ducts of medium length, terminating midway between it and est in fixed finger and basal to $t$ in movable finger; nodus ramosus not inflated.

Cephalothorax: carapace (Fig. 5) sub-rectangular; anterior margin slightly convex; with 4 setae on anterior margin and 2 on posterior margin; furrows absent; eyes completely absent. Manducatory process somewhat pointed, with 2 apical setae; median maxillary lyrifissure situated sub-basally.

Legs: femora I and II much longer than patellae I and II, respectively; femora III and IV about same size as patellae III and IV, respectively; metatarsi shorter than tarsi; subterminal tarsal seta acuminate; arolium about same length as claws, with slight medial division (Figs. 6, 7); ventral hook-shaped process absent.

Abdomen: tergite I with 2 setae; spiracular plates each with 1 seta; medial sternites without suture line; pleural membrane uniformly longitudinally striate; stigmatic helix present; anus situated between tergite XI and sternite XI.

Genitalia: female: with gonosac covered in small acetabula.

Remarks. - The arolium of B. ellisi is about the same length as the claws (Figs. 6, 7), and therefore resembles the New World genera Typhloroncus and Xorilbia Harvey and Mahnert 2006, the African Negroroncus aelleni Vachon 1958, and the Asian Dhanus siamensis (With 1906), which have arolia that are slightly shorter than the claws. The remaining ideoroncid genera have arolia that are clearly longer than the claws. It differs from these genera with short arolia by lacking the ventral hook of the arolium. It further differs from all other ideoroncids by the reduced number of trichobothria, with only 17 on the fixed finger and nine on the movable finger (Table 1, Figs. 11, 12).

Etymology.-The genus is named for its occurrence in Botswana, combined with the last five letters of Roncus, a common pseudoscorpion stem which has been thought to be derived from the Latin runco, "living in weeds" (Parker 1982). It is to be treated as masculine.

\section{Botswanoncus ellisi sp. nov. Figs. 4-12}

Material examined.-Botswana: North-western District: holotype female, Diviners Cave, Gcwihaba region, $20^{\circ} 08^{\prime} 32.2^{\prime \prime} \mathrm{S}$, $21^{\circ} 12^{\prime} 36.6^{\prime \prime} \mathrm{E}, 19$ October 2011, G. Du Preez (WAM T125604). Paratypes: 1 female, same data as holotype except 13 March 2012 (WAM T130804); 1 female, same data as paratype (NMSA-Pse 026870).

Diagnosis.-As for genus. 
Table 1.-The recorded number of trichobothria found in adults of genera of Ideoroncidae. Variant numbers are shown in brackets.

\begin{tabular}{|c|c|c|c|c|c|c|c|c|c|c|c|c|c|c|c|}
\hline & $e b$ & $e s b$ & est & et & $i b$ & isb & ist & it & $b$ & $s b$ & st & $t$ & $\begin{array}{l}\text { Fixed finger, } \\
\text { total }\end{array}$ & $\begin{array}{c}\text { Movable } \\
\text { finger, total }\end{array}$ & Reference \\
\hline Afroroncus & 1 & 1 & 6 & 1 & 4 & 1 & 5 & 1 & 2 & 1 & 1 & 6 & 20 & 10 & Mahnert (1981) \\
\hline Albiorix & 1 & 1 & 6 & 1 & $4-5$ & 1 & $5-6(4)$ & 1 & 2 & 1 & 1 & 6 & $20-22$ & 10 & Harvey \& Muchmore (2013) \\
\hline Dhanus & $1-3$ & 1 & $5-9$ & 1 & $3-6$ & 1 & $5-12$ & 1 & $2-4$ & 1 & 1 & $6-8$ & $23-31$ & $11-14$ & Mahnert $(1984,2007)$ \\
\hline Ideoroncus & 1 & 1 & 6 & 1 & $4(5)$ & 1 & $4-6$ & 1 & 2 & 1 & 1 & 6 & $20-21(22)$ & 10 & $\begin{array}{l}\text { Mahnert (1984, 2001); Harvey } \\
\quad \text { \& Muchmore (2013) }\end{array}$ \\
\hline Nannoroncus & 1 & 1 & 6 & 1 & 4 & 1 & 5 & 1 & 2 & 1 & 1 & 6 & 20 & 10 & Mahnert (1981) \\
\hline Negroroncus & $1-2$ & 1 & $6-10$ & 1 & 4 & 1 & $5-6$ & 1 & $2-3$ & 1 & 1 & $6-7$ & $20-26$ & $10-12$ & Mahnert (1981); Vachon (1958) \\
\hline Nhatrangia & 2 & 1 & 9 & 1 & 6 & 1 & $9-10$ & 1 & 4 & 1 & 1 & 8 & $30-31$ & 14 & Mahnert (1984) \\
\hline Pseudalbiorix & 1 & 1 & 6 & 1 & 4 & 1 & 5 & 1 & 2 & 1 & 1 & 6 & 20 & 10 & Harvey et al. (2007) \\
\hline Shravana & 1 & 1 & 6 & 1 & 5 & 1 & 7 & 1 & 3 & 1 & 1 & 7 & 23 & 12 & Mahnert (1984) \\
\hline Typhloroncus & 1 & 1 & 6 & 1 & $4-5$ & 1 & $6-7$ & 1 & 2 & 1 & 1 & 6 & 22 & $10(11)$ & $\begin{array}{l}\text { Muchmore (1986); Harvey \& } \\
\text { Muchmore (2013) }\end{array}$ \\
\hline
\end{tabular}

Description.-Adult: Color: pedipalps, carapace, chelicerae and coxae light red-brown, tergite I and legs pale brown and remainder light yellow-brown (Fig. 4).

Setae and cuticle: setae long, mostly straight and acicular; most cuticular surfaces smooth and glossy, with exception of pedipalps and chelicera, which are finely granulate.

Chelicera (Fig. 9): ca. 50\% length of carapace; surface reticulate; cheliceral hand with 5 setae; movable finger with 1 sub-distal seta; all setae acuminate; galea present, simple, very long, slender and slightly curved; fixed finger ca. 7 teeth, each approximately same size, small; movable finger with ca. 8 teeth, each approximately same size, small; exterior and interior condylar lyrifissures present; serrula interior with 18 blades; lamina exterior absent; rallum (Fig. 10) with 4 blades, all with anterior spinules; basal and sub-basal blades shorter than others.

Pedipalp (Fig. 8): long and slender; trochanter and femur granulate, prolateral margin of patella and chelal hand granulate, retrolateral surfaces of fingers granulate, all other surfaces smooth; setae acicular, straight or nearly so; trochanter with anterior margin rounded, $2.85 \mathrm{x}$; femur cylindrical, without trichobothria, 4.57-5.01 x; patella cylindrical, with strongly pronounced pedicel, with 3 lyrifissures, 2 at distal end of pedicel and 1 in middle of pedicel, $2.99-3.25 \mathrm{x}$; chelal hand ovoid, external chelal condyle small and rounded, internal chelal condyle small and rounded, chela (with pedicel) $3.91-4.14 \mathrm{x}$, chela (without pedicel) $3.71-3.92 \mathrm{x}$, hand (without pedicel) $1.26-1.32 \mathrm{x}$, movable finger $1.93-2.54 \mathrm{x}$ longer than hand (without pedicel). Fixed finger with 17 trichobothria; movable finger with 9 trichobothria (Figs. 11, 12); eb, esb and $i s b$ in straight row at base of finger; $i b$ region situated dorsally in the middle of chelal hand; $e b, e s b, e t, i s b$ and it regions each with 1 trichobothrium; est region with 6 trichobothria; ib region with 3 trichobothria; ist region with 3 trichobothria; et slightly distal to $i t ; b, s b$ and $s t$ regions each with 1 trichobothrium; $t$ region with 6 trichobothria; not ventrally displaced, or st situated much closer to $b$ than to $t$; trichobothrium $t$ acuminate. Both fingers straight in lateral view; chelal teeth juxtadentate (Figs. 11, 12); fixed finger chelal teeth low and flattened; venom apparatus present in both chelal fingers, venom duct of medium length, terminating midway between it and est in fixed finger and basal to $t$ in movable finger; nodus ramosus not inflated.

Cephalothorax: carapace (Fig. 5) sub-rectangular, 1.20 $1.39 \times$ longer than broad; anterior margin slightly convex; epistome absent; lateral margins slightly convex; posterior margin straight; with 18 setae, arranged 4: 4: 4: 2: 2: 2 ; setae subequal in length; furrows absent; eyes completely absent. Manducatory process somewhat pointed, with 2 apical setae, both setae approximately equal in length; maxilla with 5 additional setae; maxillary shoulder absent; median maxillary lyrifissure present, situated sub-basally, strongly curved, Ushaped; posterior maxillary lyrifissure present, strongly curved. Coxa I about same width as coxa IV; anterior margin of coxa I with process near foramen; coxae I-IV of + with setae arranged $4: 5: 4: 4$.

Legs: femora I and II much longer than patellae I and II, respectively; femur I and II without basal swelling; femora I and II with primary slit sensillum directed transversely; femora III and IV about same size as patellae III and IV, respectively; femur + patella IV $3.89 \times$ longer than broad; tibiae III and IV without obvious tactile seta; metatarsi III and IV with long tactile seta, situated medially; tarsi III and IV without tactile seta; metatarsi and tarsi of all legs not fused; metatarsi shorter than tarsi; subterminal tarsal seta acuminate; claws smooth; arolium about same length as claws, with slight medial division (Figs. 6, 7); ventral hook-shaped process absent (Fig. 7).

Abdomen: tergites straight, without suture line, setal formula + , 2: 4: 4: 4: 5: 6: 6: 6: 6: 6: 6 (arranged T1TT1T): 2; arranged in single rows; sternites, without suture line, setal formula + , 6: (1) 2 (1): (1) 4 (1): 8: 8: 8: 8: 8: 8: 6 (arranged 1T2T1): 2; setae of anterior genital operculum (sternite II) of + very small; posterior tergites and sternites with several tactile setae; glandular setae absent; pleural membrane uniformly longitudinally striate.

Genitalia: female: with gonosac covered in small acetabula.

Dimensions (mm): Female holotype (with paratypes in parentheses, where applicable). Body length 2.28 (2.16-2.25). Chelicera 0.313/0.132, movable finger length 0.200. Pedipalp: 



Figures 5-12.-Botswanoncus ellisi, new species, female holotype: 5. Carapace, dorsal; 6. Tip of left tarsus IV showing claws and arolium, dorsal; 7. Distal end of left tarsus IV, lateral; 8. Right pedipalp, dorsal; 9. Left chelicera, dorsal; 10. Rallum; 11. Left chela, lateral; 12. Left chela, lateral, showing trichobothrial pattern. Scale lines $=0.05 \mathrm{~mm}$ (Figs. 6, 7), $0.1 \mathrm{~mm}$ (Figs. 9, 10), $0.2 \mathrm{~mm}$ (Figs. 5, 11, 12), 0.5 mm (Fig. 8).

trochanter $0.314 / 0.110$, femur $0.685 / 0.150(0.659-0.722 / 0.141-$ $0.144)$, patella $0.545 / 0.182(0.502-0.550 / 0.163-0.169)$, chela (with pedicel) 1.182/0.302 (1.136-1.250/0.295-0.302), chela (without pedicel) 1.12 (1.072-1.184), hand (without pedicel) 0.380 (0.390-0.397), movable finger length 0.732 (0.689$0.768)$. Carapace $0.564 / 0.471(0.584-0.596 / 0.419-0.435)$. Leg
I: femur $0.330 / 0.080$, patella $0.160 / 0.070$, tibia $0.250 / 0.049$, metatarsus $0.152 / 0.039$, tarsus $0.337 / 0.032$. Leg IV: femur + patella $0.521 / 0.140$, tibia $0.324 / 0.071$, metatarsus $0.228 / 0.046$, tarsus $0.328 / 0.040$.

Remarks.-Botswanoncus ellisi exhibits some moderate modifications for cave existence, including the complete lack 
of eyes (Figs. 4, 5) and pallid coloration (Fig. 4). The appendages, however, are not especially elongated as in the other troglobitic ideoroncids Albiorix anophthalmus Muchmore 1999 from Arizona, USA and several Typhloroncus species from Mexican caves, which have long, slender appendages consistent with a permanent cave-dwelling lifestyle (Muchmore 1982, 1986; Muchmore \& Pape 1999; Harvey \& Muchmore 2013).

Only two other pseudoscorpion species have been recorded from Botswana. Nanolpium subgrande (Tullgren 1908) and Beierolpium deserticola (Beier 1964) (Tullgren 1908; Beier 1964), both in the family Olpiidae, making it one of the least known countries for pseudoscorpion diversity (Harvey 2013),

Etymology.-This species is named for the renowned caver Roger Ellis, who facilitated GDP's trip to Botswana. Roger has devoted over 40 years to the discovering, surveying and conserving of caves in southern Africa.

\section{ACKNOWLEDGMENTS}

We thank the government of Botswana, especially the President His Excellence Ian Khama, for creating the opportunity to explore and study the subterranean realms of the Gcwihaba district. Also, we would like to thank Roger Ellis and the rest of the Potch Potholers Caving Club for assisting our cause. Volker Mahnert and Juan Zaragoza provided very helpful comments on the manuscript.

\section{LITERATURE CITED}

Beier, M. 1964. Weiteres zur Kenntnis der PseudoscorpionidenFauna des südlichen Afrika. Annals of the Natal Museum 16:30-90.

Chamberlin, J.C. 1931. The arachnid order Chelonethida. Stanford University Publications, Biological Sciences 7(1):1-284.

Chamberlin, J.C. 1952. New and little-known false scorpions (Arachnida, Chelonethida) from Monterey County, California. Bulletin of the American Museum of Natural History 99:259-312.

Dallwitz, M.J., T.A. Paine \& E.J. Zurcher. 1999. User's Guide to the DELTA Editor. Accessed 10 January 2012. Online at http:// biodiversity.uno.edu/delta/

Harvey, M.S. 1992. The phylogeny and classification of the Pseudoscorpionida (Chelicerata: Arachnida). Invertebrate Taxonomy 6:1373-1435.

Harvey, M.S. 2013. Pseudoscorpions of the World, version 3.0. Western Australian Museum, Perth. http://www.museum.wa.gov. au/catalogues/pseudoscorpions/. Accessed 6 July 2013.

Harvey, M.S., R. Barba D., W.B. Muchmore \& A. Peréz G. 2007. Pseudalbiorix, a new genus of Ideoroncidae (Pseudoscorpiones, Neobisioidea) from central America. Journal of Arachnology 34:610-626.

Harvey, M.S. \& W.B. Muchmore. 2013. The systematics of the pseudoscorpion family Ideoroncidae (Pseudoscorpiones, Neobisioidea) in the New World. Journal of Arachnology 41:229-290.

Harvey, M.S., P.B. Ratnaweera, P.V. Randeniya \& M.R. Wijesinghe. 2012. A new species of the pseudoscorpion genus Megachernes (Pseudoscorpiones: Chernetidae) associated with a threatened Sri
Lankan rainforest rodent, with a review of host associations of Megachernes. Journal of Natural History 46:2519-2535.

Judson, M.L.I. 2007. A new and endangered species of the pseudoscorpion genus Lagynochthonius from a cave in Vietnam, with notes on chelal morphology and the composition of the Tyrannochthoniini (Arachnida, Chelonethi, Chthoniidae). Zootaxa 1627:53-68.

Mahnert, V. 1980. Pseudoskorpione (Arachnida) aus Höhlen Italiens, mit Bemerkungen zur Gattung Pseudoblothrus. Grotte d'Italia (4a) 8:21-38.

Mahnert, V. 1981. Die Pseudoskorpione (Arachnida) Kenyas. I. Neobisiidae und Ideoroncidae. Revue Suisse de Zoologie 88:535-559.

Mahnert, V. 1984. Beitrag zu einer besseren Kenntnis der Ideoroncidae (Arachnida: Pseudoscorpiones), mit Beschreibung von sechs neuen Arten. Revue Suisse de Zoologie 91:651-686.

Mahnert, V. 1985. Weitere Pseudoskorpione (Arachnida) aus dem zentralen Amazonasgebiet (Brasilien). Amazoniana 9:215-241.

Mahnert, V. 2001. Cave-dwelling pseudoscorpions (Arachnida, Pseudoscorpiones) from Brazil. Revue Suisse de Zoologie 108:95-148.

Mahnert, V. 2007. Pseudoscorpions (Arachnida: Pseudoscorpiones) of the Socotra Archipelago, Yemen. Fauna of Arabia 23:271-307.

Muchmore, W.B. 1979. Pseudoscorpions from Florida and the Caribbean area. 9. Typhloroncus, a new genus from the Virgin Islands (Ideoroncidae). Florida Entomologist 62:317-320.

Muchmore, W.B. 1982. Some new species of pseudoscorpions from caves in Mexico (Arachnida, Pseudoscorpionida). Bulletin for the Association of Mexican Cave Studies 8:63-78.

Muchmore, W.B. 1986. Additional pseudoscorpions, mostly from caves, in Mexico and Texas (Arachnida: Pseudoscorpionida). Texas Memorial Museum, Speleological Monographs 1:17-30.

Muchmore, W.B. \& R.B. Pape. 1999. Description of an eyeless, cavernicolous Albiorix (Pseudoscorpionida: Ideoroncidae) in Arizona, with observations on its biology and ecology. Southwestern Naturalist 44:138-147.

Parker, J.R. 1982. What's in a name? - scorpions and pseudoscorpions. Newsletter of the British Arachnological Society 34:1-2.

Tullgren, A. 1908. Pseudoscorpionina (Chelonethi). In: \& Schulze, L. 1908. Zoologische und Anthropologische ergebnisse einer Forschungsreise im westlichen und zentralen Südafrika ausgeführt in den Jahren 1903-1905. Denskschriften der Medizinisch-Naturwissenschaftlichen Gesellschaft zu Jena 13:283-288.

Vachon, M. 1938. Recherches anatomiques et biologiques sur la réproduction et le développement des Pseudoscorpions. Annales des Sciences Naturelles, Zoologie (11) 1:1-207.

Vachon, M. 1954. Remarques morphologiques et anatomiques sur les Pseudoscorpions (Arachnides) appartenant au genre Pseudoblothrus (Beier) (Fam. Syarinidae J.C.C.) (à propos de la description de $P$. strinatii n. sp., des cavernes de Suisse). Bulletin du Muséum National d'Histoire Naturelle, Paris (2) 26:212-219.

Vachon, M. 1958. Sur deux Pseudoscorpions nouveaux des cavernes de l'Afrique équatoriale [Ideoroncidae]. Notes Biospéologiques 13:57-66.

Vachon, M. 1969. Remarques sur la famille des Syarinidae J.C. Chamberlin (Arachnides, Pseudoscorpions) à propos de la description d'une nouvelle espèce: Pseudoblothrus thiebaudi habitant des cavernes de Suisse. Revue Suisse de Zoologie 76:387-396.

Manuscript received 4 August 2013, revised 23 September 2013. 